\title{
The Middle East Policy of America during the Cold
}

\section{War}

\author{
Tülin Tuna \\ Department of Political Science and Public Administration, Fatih University \\ 34500, Istanbul, Turkey
}

Tel: 212-866-33-00/5081 tvarli@fatih.edu.tr

Accepted: April 29, 2012 Published: June 02, 2012

Doi:10.5296/ijhrs.v2i2.1887

URL: http://dx.doi.org/10.5296/ijhrs.v2i2.1887

\begin{abstract}
This article aims to explain the Middle East policy of America during the cold war. The structure of international politics has changed after World War II. Two new powers, the United States of America and the Soviet Russia, have dominated the world politics. In this period, the Middle East was of great importance for the United States economically, politically and strategically. The United States has been struggling to prevent a power threatening the interests of the West from controlling or dominating the Middle East. Especially in the period after 1945, it has been responsive to the Soviet Union's developing control or influence over the region. In the present article, the importance of the Middle East for the United States is going to be emphasized first. Then, the doctrines called by the names of the US presidents and some conflicts and depressions experienced in this period are going to be discussed.
\end{abstract}

Key Words: the Middle East policy of USA, the Cold War, Doctrines.

\section{Introduction}

The world was reshaped after the end of World War II and a period called "Cold War" began between the Soviet Union and the United States of America which are considered as the super powers in strategic and ideological terms. ${ }^{1}$

While the Europe was struggling to get rid of the destructive effects of the World War II, the Soviet Union made effort to promulgate its ideology and the USA struggled to prevent these efforts. In addition, some changes occurred in the structure of international politics in this period and a binary structure emerged, which was called "bipolar". The basic characteristic of the bipolar world is that it is based on ideological separation. The countries in the world were

\footnotetext{
${ }^{1}$ Sait Yılmaz, Güç ve Politika (İstanbul: Alfa, 2008), p. 30 and Oral Sander, Siyasi Tarih 1918-1994 (12. bask1) (Ankara, İmge, 2003), p. 202.
} 
separated into two blocks; the "West Block" and the "East Block".

The Soviet Union was the representative of the other block or impact area against the USA with its military power almost equal to that of the USA and its ideological structure. The USA generally has been the party that kept the initiative in the creation of a new structure in the international system with the security policies it has adopted since then. The Yalta conference, February 1945, formalized the creation of these two blocks. The two super powers, the USSR and the USA, have adopted the policy of strengthening its own block since after the Yalta Conference. ${ }^{3}$

The Cold War period can be discussed in three parts. The first period was between 1945 and 1953; the second period including the period of conflict, confrontation and reconciliation was between 1953 and 1979; the third period including the second cold war period was between 1979 and $1986 .{ }^{4}$

\section{The United States and The Middle East}

The Middle East policy of the USA began when oil was found in the region in 1920s. This rich petroleum reserves and unique strategic location has made the Middle East one of the most critical regions of the modern world. The Middle East is the connecting link between Africa, Asia and Europe. It has been thought that establishing a power over the Middle East enables the USA to reach and use energy resources, notably oil, an open and secure route of transportation, seaways, the Suez Channel and the Strait of Hormuz without any obstruction. For this reason, almost every President of the United States having come to power since the World War II has emphasized that the Middle East is of great importance for the USA economically, politically and strategically. ${ }^{5}$

The military relationship between the USA and the region basically began in the Cold War era. The Middle East region is of vital strategic importance for the USA and its Western Allies. The USA struggled to certainly prevent a power threatening the interests of the West from controlling or dominating the Middle East. It thought that such situation might endanger both itself and its allies. Especially in the period after 1945, it has been responsive to the Soviet Union's developing control or influence over the region. It is seen that the policy of the USA related to ensuring the security of the region is continuous within this framework. ${ }^{6}$

To this end, the USA began to keep military power in the region when the MIDEASTFOR (Middle East Force) which utilized the Jufayr naval base of Bahrain was established in 1949. The abovementioned military power is symbolic and is of importance as it represents the Middle East policy of the USA. ${ }^{7}$

\section{Doctrines and Crises During The Cold War}

\subsection{Truman Doctrine (12 March 1947)}

The Truman Doctrine is based on the fear of American government authorities that they are continuously under the threat of the Soviet Union. This fear results from the USA's way of

\footnotetext{
${ }^{2}$ Ibid, Yilmaz, p. 30, Ibid, Sander, p. 203 and Tareq Y. Ismael, International Relations of the Contemporary Middle East (New York: Syracuse University Press, 1986), p. 136.

${ }^{3}$ Fahir Armaoğlu, 20. yüzyıl Siyasi Tarihi 1914-1980, Cilt I (Ankara: Alkım Yayınevi, 1993), p. 419, and http://history.sandiego.edu/gen/20th/coldwar1.html (available at 10. 05. 2010).

4 Yilmaz, 2008, pp. 31-37.

5 Tayyar Arı, Irak, Iran ve ABD (İstanbul: Alfa, 2004), p. 182; Ismael, 1986, p. 133 and Sander, 2003, pp. 294-295.

${ }^{6}$ Ibid, Ar1, p. 194.

7 Ibid, p. 194.
} 
interpreting the incidents having occurred in Europe after the war. ${ }^{8}$

2012, Vol. 2, No. 2

American government authorities attached importance to the fact that the Soviet Union had not withdrawn its troops from Iran just after the World War II, and requested a base in the Straits and lands in the Eastern Anatolia from Turkey and supported the communists in the civil war in Greece. This is because; these states might have directly encountered the Soviet threat. $^{9}$

If Iran and Turkey had been under the influence of the Soviet Union, all the Middle East states might have encountered the Soviet threat; if Greece had been under the control of the Soviet Union, this would have resulted in a situation threatening the security of the whole Western Europe. ${ }^{10}$

Although the Soviet troops withdrew from Iran in 1946, this crisis made the Truman government think that Iran should be enclosed creating a line against the Soviets (Containment Policy). ${ }^{11}$

Truman stated in his speech on April 5, 1946 that he was going to reshape the American foreign policy. In his speech, Truman also stated being a powerful state laid great burdens on the United States of America and getting out of these responsibilities would be a big betrayal to the international security and he added that the American foreign policy should be universal. $^{12}$

Truman explained the principles of the Middle East policy of the USA as follows:

"Turning to the Near East and the Middle East, we find an area which presents grave problems. This area contains vast natural resources. It lies across the most convenient routes of land, air, and water communications. It is consequently an area of great economic and strategic importance, the nations of which are not strong enough individually or collectively to withstand powerful aggression. It is easy to see, therefore, how the Near and Middle East might become an arena of intense rivalry between outside powers, and how such rivalry might suddenly erupt into conflict. No country, great or small, has legitimate interests in the Near and Middle East which cannot be reconciled with the interests of other nations through the United Nations. The United Nations have a right to insist that the sovereignty and integrity of the countries of the Near and Middle East must not be threatened by coercion or penetration." $" 13$

In his speech on March 12, 1947 in the Congress, he said that independent nations sought the support of the United States of America and the world peace would fall into danger if the USA was indecisive about providing this support. ${ }^{14}$ Therefore, Truman requested from the

\footnotetext{
8 Sander, 2004, p. 257.

9 Ibid, p. 258 and Ar1, 2004, p. 218.

10 Ar1, Ibid, p. 218.

${ }^{11}$ Charles A. Kupchan, The Persian Gulf and the West: The Dilemmas of Security (Boston: Ullen and Unwin, 1987), p. 14 and Sander, 2004, p. 258.

${ }_{12}$ Mustafa Oral, "Tarihsel Perspektifte ABD’nin Orta Doğu Politikası ve Türkiye”, http://www.turksolu.org/ileri/28/oral28.htm (available at 10. 05. 2010).

13 Mehmet Gönlübol, Olaylarla Türk Dış Politikası (1919-1995), 9. Baskı (Ankara: SBF Yayınları, 1996), p. 203.

14 Bruce Kuniholm, "Retrospect and Prospects: Forty Years of U.S. Middle East Policy", The Middle East Journal 41 (1987), p. 11 .
} 
Congress to give 400 million Dollars to Turkey and Greece as an economic aid and to send American civil and military personnel to these countries to modernize their military equipments and armies. ${ }^{15}$

Along with the proclamation of the Truman Doctrine and the increased American commitments in the Middle East, the British - Soviet rivalry in the region was replaced by the rivalry between the USA - the Soviets. In addition, this doctrine can be regarded as the first step towards the Cold War to continue until 1990 with increases and decreases in tempo. $^{16}$

\subsection{Marshall Plan (1947)}

This plan is related to the economical development of Europe and it has a different meaning from the Truman Doctrine that can be regarded as the starting point of the Cold War. ${ }^{17}$ George Marshall, the USA Secretary of State, observed that the Europe could not recover itself yet after the World War II and stated that the USA should give more economic help to the Europe, in his visit in the continent for the Moscow Conference. This was because a stable Europe with no economic barrier would have enlarged the import market of the USA and therefore served to American interests. ${ }^{18}$ However, the European countries should have taken action before the American assistance. The first draft of the European Development Project called Marshall Plan was issued in the conference held in Paris on July 12, 1947 with the participation of 16 states. In the light of the data obtained from the 16 European states, the reports regarding how much assistance these states need were issued and these reports were sent to the USA. Therefore, the Marshall aid covering four years (1947-1951) was launched. ${ }^{19}$

\subsection{The Establishment of the State of Israel \& Arab-Israel Conflict (1948)}

After the World War II, one of the main factors influencing the political developments in the Middle East was the establishment of the State of Israel. The relationship among the Arab states and the relationship between the Arab states and other countries were based on the Israel-Arab conflict which had risen since 1945.

The Jews began to struggle to establish a State of Israel before the World War II. The most important support regarding this aim was given by England which holds the mandate government. England initially imposed a quota on the Jews going to Palestine in order to find a compromise; however, this resulted in the illegal migration of the Jews who escaped from the coercion of Hitler in Europe to Palestine. England was torn between the Jews to whom it promised a national country and the oil-related interests and Palestine located in a strategic region. $^{20}$

England lost power after the World War II and handed over the Palestine problem to the UN declaring that it decided to terminate the mandate government in Palestine. The UN concluded that Palestine be shared by Arabs and Jews and Jerusalem remain neutral. In accordance with this decision, England terminated its mandate government in the region on

\footnotetext{
15 Sander, 2004, p. 258 and John W. Spanier, American Foreign Policy Since World War II (New York:Holt, Rinehalt and Winston, 1980), pp. 28-29.

16 Sander, 2004, p. 259 and Ar1, 2004, p. 220.

17 Ibid, Sander, p. 259.

18 Ayşegül Sever, Soğuk Savaş Kuşatmasında Türkiye, Batı ve Ortadoğu (İstanbul: Boyut, 1997), pp. 53-54.

19 Sander 2004, p. 260.

20 Ibid, p. 298, and Fahir Armaoğlu, 20.Yüzyll Siyasi Tarihi(1914-1995) (İstanbul: Alkım, 2004), p. 484.
} 
May 14, 1948 and Israel declared its independence. ${ }^{21}$ The new state was recognized by the United States and the Soviet Union as well. However, seven Arab states including the Arabs who had been residing in the region for one thousand years, Egypt, Syria, Lebanon, Jordan, Iraq, Saudi Arabia and Yemen made a military intervention in the region in order to prevent the implementation of the decision of the United Nations. ${ }^{22}$ As Israel acquired new lands with the related conflicts, the Palestinian people became refugees. ${ }^{23}$ The armistice lines occurred at the end of the 1948 War were accepted as the borders of Israel. However, Arab States did not recognize this state and the 1956, 1967, 1973 Arab - Israel Wars outbroke. ${ }^{24}$

\subsection{Baghdad Pact}

In the Truman period, British and American experts wanted a Middle East Defence Organization to be established in order to prevent the Soviet Russia from infiltrating in the Middle East. It was thought that Egypt would play a key role under the leadership of England and with the support of the United States. However, such plan could not be realized due to the reaction of Arabs. Then, the Baghdad Pact was adopted with an agreement between Turkey and Iraq in 1955 with the United States' encouragement. In April 1955, England; in September 1955, Pakistan and in November 1955, Iran joined the Bagdad Pact, thereby enlarging the alliance. ${ }^{25}$

While England was the only Western member of the Pact, the United States did not want to come to Israel's attention by joining the Pact in this period when Arab - Israel conflict was at issue. Therefore, the United States did not establish a legal connection with the Pact. ${ }^{26}$

The Baghdad Pact was not long lived. Initially, Iraq declared that it would pursue a nonalignment policy and thereon bipartite defence agreements were signed between Turkey, Iran, Iraq and Pakistan. However, Iran declared that it withdrew from the Pact in 1959. The remainder members constituted the Central Treaty Organization (CENTO) until the Iranian Reform in $1979 .^{27}$

\subsection{Suez Crisis}

In a sense, the developments related to the 1956 Suez Crisis were the continuation and natural results of the conflicts between England and Egypt after the World War II. ${ }^{28}$

During the World War II, when Germany wanted to capture the Suez Channel deploying soldiers to Egypt, England deployed two hundred thousand soldiers to the lands of Egypt on the strength of the 1936 alliance. When the war ended, negotiations were started with England upon the request of Egypt in 1945 and these two states signed an agreement in 1949. England accepted that it would gradually withdraw from Egypt until September 1949. However, the efforts by the Soviet Union to take Iran, Turkey and Greece under control in 1945-46 resulted in the 1948-49 Arab - Israel War and the non-withdrawal of the soldiers of England. Egypt rejected the attitude of England and declared that it annulled the Suez

\footnotetext{
${ }^{21}$ Ali Balcı, "Filistin: Savaş ve Barış Arasında" Edited by Kemal İnat, Dünya Çatışma Bölgeleri (Ankara: Nobel yayınları, 2004), pp. 40-41.

22 Sayim Türkman, ABD-Ortadoğu ve Türkiye (Ankara: Nobel, 2007), pp. 201-202.

23 Halis Çevik, Kadim toprakların Trajedisi Ortadoğu (Konya: NKM, 2005), p. 242.

${ }^{24} \mathrm{http}: / /$ www.tarihportali.net/tarih/ortadogu-t6550.0.html;wap2 (available at 11.04.2010).

25 Ar1, 2004, p. 221

26 Ibid, p. 222.

27 Ibid, p. 226.

28 Ömer Kürkçüoğlu, Türkiye'nin Arap Ortadoğu'suna Karşı Politikası (Ankara: SBF, 1972), p.81.
} 
Agreement dated 1936. ${ }^{29}$ Whereupon conflicts occurred between the British Forces and the local people in the Suez Channel. In addition, England and France made a joint assault against Egypt in order to avoid possible material damages to the Channel region. The USA and the Soviet Union showed a harsh response to this clear attack in the presence of the United Nations. Two rival states liaised in this situation; and England and France had to withdraw their troops against this unusual oppression. ${ }^{30}$

Consequently, the Suez Crisis has made a significant change in the situations of the two Western states having a say in the Middle East since the period between the two wars in 1919 and 1939. England and France categorically withdrew from the Middle East and the United State of America superseded them due to the abovementioned crisis. ${ }^{31}$

In addition, Egypt established a full control over the Suez Channel as a result of the Suez Crisis. It made England withdraw its bases and it terminated the British dominance in Egypt which had been lasting since 1881. Egypt became the most effective and powerful country of the Arab world. The Soviets which expressed its strong condemnation for the Western states' attack to Egypt and channel region gained prestige in the Middle East and Egypt began to warm towards the Soviets. The United States of America gained prestige in the region as well because it was clearly against the attack and it did not have a imperialist history in the region; however, the Eisenhower Doctrine, which the USA adopted against the Soviet policy in the region and which can be regarded as one of the results of the Suez Crisis, was interpreted as an arrangement directed to protect the interests of the West and damaged the prestige of the USA in the region in the long run. ${ }^{32}$

\subsection{Eisenhower Doctrine}

As stated before, the Eisenhower Doctrine emerged as a result of the 1956 Suez Crisis. This is because; the situation in the Middle East after the Suez Crisis worried the United States of America. The substantial Western prestige in the region was damaged while the Soviet Russia became the saver of the Arab world.

Eisenhower made effort to enable these countries to struggle against communism by helping the countries in the region to solve and strengthen their economic problems explaining what communism hegemony could result in. ${ }^{33}$ This is because; The United States of America understood that it could not protect the regions surrounding the Soviet Union through regional assaults and control the situation in the Middle East abiding by a solely military doctrine like the Truman Doctrine in the reformist change period that the Middle East underwent after the Suez Crisis, and it adopted a new political program to gain the trust of local people and to remove the image of "colonist" and a new aid to support this program. ${ }^{34}$

Due to the abovementioned reasons, the President Eisenhower declared the decision of the USA to supersede England and France in the Middle East in his message presented in the American Congress on January 5, 1957, which is called "Eisenhower Doctrine". ${ }^{35}$ In his

\footnotetext{
${ }^{29}$ Fahir Armaoğlu, Filistin Meselesi ve Arap İsrail Savaşları (Ankara: İş bankası, 1989), p.117 and Armaoğlu, 2004 , p. 493.

30 Sander, 2004, p. 303.

31 Kürkçüoğlu, 1972, p. 90.

32 Sander, 2004, pp. 304-305.

33 Fahir Armaoğlu, Belgelerle Türk-Amerikan Münasebetleri (Ankara: TTK, 1991), p. 240.

34 Oral Sander, Türk-Amerikan İlişkileri (1947-1964) (Ankara: SBF, 1979), pp. 149-150.

35 Kürkçüoğlu, 1972, p.114.
} 
message, he expressed that the Middle East became a unstable region in time and suggested that this instability was exploited by "international communism". Eisenhower stated that Russia had no economic interest over the Middle East and did not need the oil in the Middle East and added that the USA was already an oil-exporting country. Therefore, he argued that the interest of Russia in the Middle East was fully based on political purposes and emphasized that Russia would like to seize this region due to its strategic importance. ${ }^{36}$ Due to these reasons, the President submitted the Congress his proposal consisting of four items. These items were to give economic aid to the Middle East countries struggling for economic development in order to protect their independency or to give military aid to the demanding countries; to use the American armed forces against obvious armed assaults by a country under the control of international communism when requested, and to allocate two million Dollars to the order of the President for 1958 and $1959 .{ }^{37}$

Consequently, the Eisenhower Doctrine which is a step towards the re-acceleration of the Cold War and which provides more opportunities for the United States of America to intervene in the region did not fulfil the expectations of the USA. This mainly resulted from the fact that the doctrine was considered as a direct intervention in the internal affairs of the Middle East by Egypt and Syria, although it was backed up by Lebanon, Libya, Turkey, Iran and Iraq. Moreover, Syria and Egypt warmed towards the Soviet Union and this convergence gave rise the tendency to communism in Syria. ${ }^{38}$

\subsection{Syria Crisis}

The Syria - Soviet Union convergence after the Suez Crisis and before the proclamation of Eisenhower Doctrine caused anxiety in Turkey and the USA. That the Syrian government was pro-Soviet and the weapons manufactured in Soviets were sent to Syria caused mistrust among Turkey and other members of the Baghdad Pact. The Soviet presence in Syria worried the Turkish government because the dominance of the Soviet Union in Syria meant that Turkey would be enveloped from the south and surrounded on three sides as Turkey borders Bulgaria in the west and the Soviets in the north. In a declaration published by the Turkish Ministry of Foreign Affairs, it was stated that Turkey would take the necessary precautions when the Soviet Union deployed troops in Syria. ${ }^{39}$

In a message sent by the United States of America to Turkey, it was stated that the USA would give hand to Turkey in case of an assault by the Soviet Union. The USA deployed its naval and air forces in the region and performed military manoeuvres in the southern borders of Turkey in order to warn Syria. However, the precautions taken by Turkey tensed up the relationships between Turkey and Syria rather than softening Syria. The USA's declaration that it was on Turkey's part prompted Syria. The Soviets oppressed Turkey using their full influence on Syria. Then, the United Stated of America put its full support behind Turkey. Therefore, the USA proved that the Eisenhower Doctrine can be implemented in the Middle East in October $1957 .^{40}$

This crisis is a result of the outbreak of the steadily increasing dominance and power rivalry

\footnotetext{
${ }^{36}$ Ibid, p. 115.

37 Hüseyin Bağcı, Türk Dış politikasında 1950’li Yıllar (Ankara: METU, 2001), p.85; Sander, 2004, pp. 306-307; Arı, 2004, p. 224.

Sander, 1979, p.152.

39 Bağc1, 2001, p. 90.

40 Armaoğlu, 1991, p. 508.
} 
started between the two blocks after 1945 - 1947 in the Middle East. This dominance and power convergence having appeared as a long cold war caused the two blocks to indirectly oppose each other in several regions from time to time, which is nothing but what was observed during the Syria Crisis. The Soviet Union which took advantage of the domestic situation in Syria chose Syria as a suitable region to dominate the Middle East. However, the Western countries did not want communism to dominate this region and therefore they wanted to prevent the Soviet Union from dominating Syria. ${ }^{41}$

\subsection{Lebanon Crisis}

The policy adopted by Lebanon related to participating in the organizations supported by the USA and the West in order not to be seen as a pro-West changed with the proclamation of the Eisenhower Doctrine and Lebanon was the second Arab country to adopt the related doctrine after Iraq. $^{42}$

When the Eisenhower Doctrine was adopted in Lebanon, the general elections were held and the President Camille Chamoun practised a deceit in these elections and managed to enable a parliament to win the elections, which would support the Eisenhower Doctrine and would enable his presidency term which would have otherwise expired in September, 1958 to be prolonged for another four year period although it was not possible in accordance with the constitution. In these elections, the most important figures of the opposing party were excluded from the parliament. However, the Muslim-Arab section of the Lebanese people, half of whom were Christian and half of whom were Muslim, basically were pro-Nasir and did not support the Eisenhower Doctrine. ${ }^{43}$

The abovementioned tricks by Chamoun caused a severe opposition against him as well as dividing the Lebanese people into two. As this was the case, the murder of a journalist connected to the opposing party on May 8, 1958 was enough to create trouble and Nasir supporters went on strike arguing that this murder was organized by the government and these strikes turned into a real rebel. Whereupon, this rebel turned into anti-Westism. ${ }^{44}$

Following that the Lebanese primary minister, Chamoun invited the USA to Lebanon, where a domestic disturbance existed, based on the Eisenhower Doctrine, the US naval forces attacked Lebanon. ${ }^{45}$ In the message that the US President Eisenhower sent to the Congress, he explained that the stated military attack was performed upon the request of Lebanon. ${ }^{46}$

The number of the US soldiers was raised to 15.000. Chamoun abandoned the decision of prolonging the presidency term with the pressures of the USA. Then, the Lebanon parliament elected the Commander of the Lebanese Armed Forces, Sahab as a prima minister with a great majority. The Commander Sahab had held the armed forces in full neutrality since the outbreak of the cases in May 8, was not involved in the domestic conflicts, while making efforts to prevent these cases from turning into a civil war. Thus, the Lebanon Crisis broke out in May settled at the end of July. ${ }^{47}$

\subsection{Nixon Doctrine}

41 Gönlübol, 1996, p. 299.

42 Sever, 1997, p. 218.

43 Armaoğlu, 1991, p. 511.

${ }^{44}$ Ibid.

45 Sander, 1979, p.166.

46 Gönlübol, 1996, p. 302.

47 Armaoğlu, 1991, p. 511. 
The United States started a major change in its Gulf Policy with the influence of the burden of Vietnam after a short while after the President Richard M. Nixon took over the administration. The abovementioned change focused on how the Nixon Doctrine which was proclaimed in 1969 would be implemented in the region. ${ }^{48}$

Nixon stated that the world was going into a change after the World War II and a foreign policy to fulfil the requirements of this new era should be created. In addition, the developments having emerged in line with the detente in the international system was effective in this policy change as well. ${ }^{49}$

Nixon Doctrine basically envisaged that the USA would not perform direct military interventions in regional conflicts but rather be contented with giving military and economic aids. In this connection, the USA changed its Gulf policy. The purpose of the USA was not to supersede England in the region but to develop diplomatic relations with the states in the region and to give economic and technical assistance and thereby to encourage the efforts of these states. However, the states in the region were responsible for the security in the region. ${ }^{50}$

The Nixon Doctrine involved utilizing the local partners in critical geographies and expanding the scope of the roles of these partners in order to promote and maintain the American hegemony. The USA controlled the Middle East and the Gulf adopting a twin pillar policy. Iran and Saudi Arabia took significant parts in this policy. ${ }^{51}$ According to the Nixon plan, "the capacities of those states to be responsible for the defence of the region would be improved with the American weapons in terms of quality and quantity.", 52

Therefore, the USA's policy directed to remove the image based on a security-oriented cooperation between the USA and the countries in the region mainly focused on four points. First of all, the cooperation between Iran and Saudi Arabia should be encouraged in order to ensure the stability in the Gulf region. Secondly, the USA should maintain a part of its naval forces despite probable oppositions in the Gulf. Thirdly, the USA should increase the number of its diplomatic representatives in the Gulf Region and improve its technical assistance. Finally, the USA should support the weak countries in the Gulf region. ${ }^{53}$

After this period, the stated policy dominated the period until the 1979 Iranian Reform and the invasion of Afghanistan by the Soviets. Moreover, in case any power established dominance over the region in a way to create imbalance or it increased its influence over the region, this would endanger the security of the oil and the interest of the West over the region. Therefore, it was emphasized that such dominance would be against the interests of the USA. $^{54}$

\subsection{Iranian Reform and the Developments in Afghanistan}

The United States of America significantly relied on its alliance with Iran for the security of the Gulf region during the Nixon administration. However, the Middle East and the Gulf policy of the USA took an unexpected blow with the Iranian Reform in 1979. Not only the

\footnotetext{
48 Ar1, 2004, p. 226 and http://www.merip.org/mer/mer243/plitnick_toensing.html (available at 12.04.2010).

49 Ibid, p. 227 and Joseph S. Jr. Nye, Amerikan Gücünün Paradoksu (İstanbul: Literatür Yayınc1l1k, 2003), p. 194.

50 Ibid, p. 228.

51 Ibid and Gary Sick, "Rethinking Dual Containment", Survival 40 (1998), p. 6.

52 Ar1, Ibid, and Sick, Ibid, p. 7.

53 Ar1, 2004, p. 229.

${ }^{54}$ Ibid.
} 
USA lost one of its significant allies in the region but also Iran became a new threat factor for the states in the region. ${ }^{55}$

The Iranian administration came under the domination of the Islamist group which was against the USA and the West with the overthrow of the Shah. Hence, the Soviet Union became advantageous against the USA. This is because; the two pillar policy that the USA adopted came to an end following the regime change in Iran. Therefore, the reliability of the USA's Middle East policy took a blow and the security of its allies came under threat. The developments in Iran in 1978 and 1979 made it necessary to review the Nixon Doctrine. ${ }^{56}$

The developments in Afghanistan caused the World War which went down with the invasion of Afghanistan in December 1979 by the Soviet Union to rise again. The strategic, economic and political interests of the USA over the region were endangered with the abovementioned invasion. The security problem of the political regimes in the region was raised due to the developments in Iran. ${ }^{57}$

Both the Iranian Reform and the invasion of Afghanistan were interpreted as the most negative developments during the post-World War II era for the USA. ${ }^{58}$

\subsection{The Carter Doctrine and the Rapid Deployment Force}

After Jimmy Carter came into power, the Nixon Doctrine which had constituted the basis for the Middle East policy of the USA by that time was terminated and a policy was adopted, which is called the "Carter Doctrine". This policy which legalized the military intervention of the USA has constituted the basic axis of the US Middle East Policy since then. ${ }^{59}$

Carter declared this policy on January 23, 1980. He briefly suggested that; an attempt by any outside force to gain control of the Persian Gulf region will be regarded as an assault on the vital interests of the United States of America and such an assault will be repelled by any means necessary, including military force. ${ }^{60}$ This policy exhibited an attitude completely opposite to the Nixon Doctrine which emphasized a weapon aid to encompass the Soviet diffusion. Since then, American armed forces would be used to defence the American interests in the Persian Gulf region.

The Carter administration established a Rapid Deployment Force in December 1979 basically in order to ensure the security of the Gulf Region and to protect the economic interests of the United States of America in the Gulf region upon the developments having arisen with the invasion of Afghanistan and the overthrow of the Shah in Iran. The Rapid Deployment Forces were initially established in order to dissuade or to stop for a certain time any possible Soviet assault to the region. ${ }^{61}$ Then a new joint task force was proposed to be established with a project prepared by the US Naval Forces and a Rapid Deployment Joint Task Force (RDJTF) combining the two projects was established as a result of the studies which had been carried out between December 1979 and February 1980. ${ }^{62}$ The purpose of the Rapid Deployment

\footnotetext{
55 Robert Divine, America: Past and Present, translated by İhsan Dağı, (Ankara: Dış Politika Enstitüsü, 1994), p. 250; Arı, 2004, p. 231.

56 Ibid, 1994, p. 251 and Ibid, 2004, pp. 232-233.

57 Ibid, 1994, p. 253 and Ibid, 2004, p. 236.

58 Ibid, 2004, p. 236.

59 Ramazan Özey, Dünya Denkleminde Orta Doğu (İstanbul: Öz Eğitim, 1997), p. 27.

${ }^{60}$ Ismael, 1986, pp. 155-156.

61 Ar1, 2004, p. 239.

62 Ibid, p. 240.
} 
Force was to keep available a qualified and mobile military force which has the ability to combat under desert conditions in order to be able to intervene in the Gulf region when necessary. However, it was emphasized that the mobility of the abovementioned task force should be improved when the Rapid Deployment Task Force could not be effective in the crisis in which the US embassy personnel in Tehran were taken hostage. ${ }^{63}$

\subsection{Post-1980 Period and the US Central Command (CENTCOM)}

Ronald Reagan came into power in 1981 after Carter who encountered vital cases in the region having come into power in 1977. Reagan preferred a more aggressive discourse during the period before the elections and stated that the USA would give rise to military steps towards the region reminding that the Rapid Deployment Force failed in the hostage crisis in Iran. Hence, that Reagan doubled the defence budget proposed by the Carter administration for 1981 and 1982 was a big indicator of the march of the policy of the new president regarding the region. ${ }^{64}$ The basic policy of the Reagan administration was to respond harshly to the enlargement of the Soviet Union and to take the lead in adopting a containment policy in universal terms. ${ }^{65}$

In addition to the abovementioned policy adopted against the Soviet Union, other elements of the Middle East policy of the Reagan Administration were maintaining the Rapid Deployment Force policy which ensures the presence of US troops in the region and increasing the number of these troops. The Rapid Deployment Force began to gain much more importance along with the Reagan administration. As stated before, that Reagan supported the Rapid Deployment Force policy and especially increased the military budget resulted in a rapid increase in the dominance of the USA over the region. In a press conference in February 1981, Reagan stated that he would maintain the Rapid Deployment Policy of Carter in the Persian Gulf and other regions of the Third World in order to protect the American interests. ${ }^{66}$ As is known, the establishment purpose of the Rapid Deployment Force was to respond to the threats against the Gulf Region. This task force became more effective during the Reagan administration. In addition, Francis West, the US Deputy Secretary of Defence, listed other missions of the Rapid Deployment Force as follows; to continually ensure the security of Israel and peace in the region, to support moderate Arab states such as Saudi Arabia, Jordan, Oman and Egypt against radical states, to support moderate Arab states against civil rebellions and subversive activities, to limit the Soviet influence over the region and to dissuade a possible Soviet invasion in the Gulf region. ${ }^{67}$

In addition, the name of Rapid Deployment Joint Task Force (RDJTF) was changed to the US Central Command (CENTCOM) in January 1983 by the Reagan administration and its capacity was increased. The USA developed various policies in order to ensure that the Rapid Deployment Force moves in the region more readily. At this point, the military agreements in the region and the bases had a very significant role in terms of the permanence of the military presence of the Rapid Deployment Force and the USA. The Rapid Deployment Force which had been initially established for the purpose of creating a deterrent

\footnotetext{
63 Ibid, p. 241.

${ }^{64}$ Ar1, 2004, p. 244.

65 Ibid, p. 243.

${ }^{66}$ Ibid, p. 244.

${ }^{67}$ Ibid, p. 245.
} 
factor for the Soviet threat was deployed in the region thereafter and played a significant role in the US military interventions in the region. ${ }^{68}$

\section{Conclusion}

The political structure having emerged after the World War II in the world was built upon a balance of power created by the West Block under the leadership of the USA on one side and the East Block under the leadership of the Soviet Union on the other side. The security of the Middle East which was one of most important centres in world politics had a great role in this era. The USA adopted a policy that would continuously increase its hegemonic power in the Middle East.

In this period, various doctrines were proclaimed under the names of the US presidents. The USA promised that it would protect the independent nations against the danger of Communism with the Truman Doctrine in 1947. With the Eisenhower Doctrine in 1957, it also declared that it would give a direct military aid when requested by the nations facing the threat of international communism while forming the legitimate basis for using a direct military power. The 1960s when the tension was still felt despite the detente was a significant period for the US Foreign Policy. The USA struggled to create an interest-based structure all over the world against the Soviet threat. The USA declared that no military power would be used in regional conflicts thereon with the 1968 Nixon Doctrine and took a step back from the US policy having been adopted up to that time. However, this political detente adopted within the context of the Nixon Doctrine, the Iranian Reform, the invasion of Afghanistan and other cases during 1970s caused the USA to adopt an interventionist policy again under the name of the Carter Doctrine in 1980. This interventionist policy was initially considered for the Middle East; however it was expanded in a way to cover all the regions where American interests were under threat with the Reagan administration.

Consequently, when these doctrines are analyzed, it is seen that the USA actually adopted a sustainability and development policy in the Middle East. In addition, although the Soviet Union was introduced as a big threat for the Middle East by the USA, the USA itself was dangerous as much as the Soviet Union.

\footnotetext{
${ }^{68}$ Ibid, p. 246.
} 


\section{Macrothink}

\section{References}

Arı, T. (2004). Irak, Iran ve ABD, İstanbul: Alfa.

Armaoğlu, F. (1993). 20. yüzyıl Siyasi Tarihi 1914-1980, Ankara: Alkım Yayınevi, (Cilt I).

Armaoğlu, F. (2004). 20.Yüzyıl Siyasi Tarihi 1914-1995, İstanbul: Alkım.

Armaoğlu, F. (1991). Belgelerle Türk-Amerikan Münasebetleri, Ankara: TTK.

Armaoğlu, F. (1989). Filistin Meselesi ve Arap İsrail Savaşları, Ankara: İş bankası.

Balcı, A. (2004). "Filistin: Savaş ve Barış Arasında" Edited by Kemal İnat, Dünya Çatışma Bölgeleri, Ankara: Nobel.

Bağcı, H. (2001). Türk Dış politikasında 1950'li Yıllar, Ankara: METU.

Çevik, H. (2005). Kadim toprakların Trajedisi Ortadoğu, Konya: NKM.

Divine, R. (1994). America: Past and Present, translated by İhsan Dağı, Ankara: Dış Politika Enstitüsü.

Gönlübol, M. (1996). Olaylarla Türk Dış Politikası (1919-1995), Ankara: SBF Yayınları.

Ismael, Tareq Y. (1986). International Relations of the Contemporary Middle East, New York: Syracuse University Press.

Kuniholm, B. (1987). Retrospect and Prospects: Forty Years of U.S. Middle East Policy. The Middle East Journal 41.

Kupchan, Charles A. (1987). The Persian Gulf and the West: The Dilemmas of Security, Boston: Ullen and Unwin.

Kürkçüoğlu, Ö. (1972). Türkiye’nin Arap Ortadoğu'suna Karşı Politikası, Ankara: SBF.

Nye, Joseph S. Jr. (2003). Amerikan Gücünün Paradoksu, İstanbul: Literatür Yay.

Özey, R. (1997). Dünya Denkleminde Orta Doğu, İstanbul: Öz Eğitim.

Sever, A. (1997). Soğuk Savaş Kuşatmasında Türkiye. Batı ve Ortadoğu, İstanbul: Boyut.

Sick, G. (1998). Rethinking Dual Containment, Survival 40.

Spanier, John W., (1980). American Foreign Policy Since World War II, (New York: Holt, Rinehalt and Winston.

Sander, O. (1979). Türk-Amerikan İlişkileri (1947-1964), Ankara: SBF.

Sander, O. (2003). Siyasi Tarih 1918-1994, Ankara: İmge.

Türkman, S. (2007). ABD-Ortadoğu ve Türkiye, Ankara: Nobel.

Yılmaz, S. (2008). Güç ve Politika, İstanbul: Alfa.

Available: http://history.sandiego.edu/gen/20th/coldwar1.html (May 10, 2010).

Available: http://www.merip.org/mer/mer243/plitnick_toensing.html (May 12, 2010).

Available: http://www.tarihportali.net/tarih/ortadogu-t6550.0.html;wap2 (May 11, 2010).

Mustafa Oral, (2010), Tarihsel Perspektifte ABD'nin Orta Doğu Politikası ve Türkiye. [Online] Available: http://www.turksolu.org/ileri/28/oral28.htm (May 10, 2010). 